\begin{tabular}{|c|c|c|c|c|c|c|}
\hline \multirow{4}{*}{ Impact Factor: } & ISRA (India) & $=3.117$ & SIS (USA) & $=0.912$ & ICV (Poland) & $=6.630$ \\
\hline & ISI (Dubai, UAE & $=0.829$ & РИНЦ (Russia & $=\mathbf{0 . 1 5 6}$ & PIF (India) & $=1.940$ \\
\hline & GIF (Australia) & $=0.564$ & ESJI (KZ) & $=8.716$ & IBI (India) & $=4.260$ \\
\hline & JIF & $=1.500$ & SJIF (Morocco & $=\mathbf{5 . 6 6 7}$ & OAJI (USA) & $=0.350$ \\
\hline
\end{tabular}

\section{SOI: $1.1 /$ TAS DOI: $10.15863 /$ TAS International Scientific Journal Theoretical \& Applied Science}

\author{
p-ISSN: 2308-4944 (print) e-ISSN: 2409-0085 (online) \\ Year: 2019 Issue: $04 \quad$ Volume: 72
}

Published: $24.04 .2019 \quad$ http://T-Science.org
QR - Issue

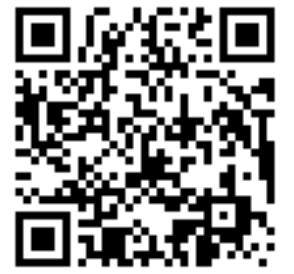

Khasan Shaymanovich Abdinazarov

Senior Lecturer, English language teacher, researcher Department of Foreign languages Karshi Engineering-Economic Institute Karshi, Uzbekistan abdinazarov_2017@mail.ru

\title{
TOKENS AND TYPES OCCURRING IN ESP CONTEXTS
}

\begin{abstract}
In teaching English for specific purposes, we focus on technical context to teach because there are some tokens and types which students of engineering need to acquire in order to use them in spoken context. Any text is full of collections and frequency words which describe how many tokens and types may exist in the context of specialty, especially, mining engineering. However, we may see strong tokenization in the context of engineering. This paper highlights discussions of scholars on the issues of corpus linguistics, especially, collocations, tokens and types.

Key words: tokens, types, corpus linguistics, ESP context.

Language: English

Citation: Abdinazarov, K. S. (2019). Tokens and Types Occurring in ESP Contexts. ISJ Theoretical \& Applied Science, 04 (72), 313-315.

Soi: http://s-o-i.org/1.1/TAS-04-72-35 Doi: crossef https://dx.doi.org/10.15863/TAS.2019.04.72.35

\section{Introduction}

The growth of corpus linguistics (McCarthy 1998) has convinced linguists that vocabulary is much more than the 'unordered list of all lexical formatives' which Chomsky (1965:84) referred to it. Pioneering studies of large corpora by linguists such as Sinclair (1991) have shown lexis to be a far more powerful influence in the basic organization of language and of meaning than was ever previously conceived. Corpora reveal that much of our lexical output consists of multi-word units; language occurs in ready-made chunks to a far greater extent than could ever be

Sinclair (1966). Both Halliday and Sinclair foresaw in the papers the development of the computational analysis of lexis using large amounts of text. Collocation studies show, most importantly, that a good deal of semantically transparent vocabulary is to a greater or lesser degree fossilized into restricted patterns ( Aisenstadt 1981). Moreover, there are some tokens and types occurring in the context of specialty, which is more needed for acquisition of technical vocabulary. A present study shows text analysis, indicating, discussing; collocations, corpora, and tokens and types in the texts.
\end{abstract} accommodated by a theory of language insistent upon the primacy of syntax. Recent developments in the study of lexis have generated new applications within lexicography and language teaching, offering the possibility of a better understanding of the nature of the lexicon, especially multi-word phenomena. Besides, the notion of collocation shifts the emphasis from the single word to pairs of words as integrated chunks of meaning in the contexts, and collocation has become an uncontroversial element in a good deal of language description and pedagogy. Collocations are not absolute or one hundred percent deterministic, but are the probabilistic outcomes of repeated combinations created and experienced by language users. Key discussions of the implications of Firth's theory of collocation appear in Halliday (1966) and

\section{Words in Corpora}

Sinclair (1987, 1991), based on his lexicographic studies of collocation in the Birmingham Collection of English Text (later known as The Bank of English), sees two fundamental principles at work in the creation of meaning. These he calls the idiom principle and the open choice principle. The idiom principle is the central one in the creation of text and meaning in speech and writing, and works on the basis of the speaker/writer having at his/her disposal a large store of ready-made lexicogrammatical chunks. Syntax, far from being primary, is only brought into service occasionally, as a kind of 'glue' to cement the chunks together. Sinclair (1996) 


\begin{tabular}{|c|c|c|c|c|c|c|}
\hline \multirow{4}{*}{ Impact Factor: } & ISRA (India) & $=3.117$ & SIS (USA) & $=0.912$ & ICV (Poland) & $=6.630$ \\
\hline & ISI (Dubai, UAE & $=0.829$ & РИНЦ (Russia) & $=0.156$ & PIF (India) & $=1.940$ \\
\hline & GIF (Australia) & $=0.564$ & ESJI (KZ) & $=8.716$ & IBI (India) & $=4.260$ \\
\hline & JIF & $=1.500$ & SJIF (Morocco & $=5.667$ & OAJI (USA) & $=0.350$ \\
\hline
\end{tabular}

sees form and meaning as complementary: different senses of a word will characteristically be realized in different structural configurations. This extends the original notion of collocation to encompass longer strings of words and includes their preferred grammatical configurations or colligations (Mitchell 1971). The unitary consequences of collocation and colligation produce meaningful strings or chunks which are stored in memory (Bolinger 1976) and which substantiate the idiom principle. The relationship of collocation is fundamental in the study of vocabulary; it is a marriage contract between words, and some words are more firmly married to each other than others. Any word in the language can be examined from point of view of grammar, and viceversa, any word, even words like verbs and conjunctions can be considered as vocabulary items. Languages are full of strong collection pairs and, therefore, collocation deserves to be a central aspect of vocabulary study. Knowledge of collocation is knowledge of what words are most likely to occur together (Michael McCarthy 2006; 12).

\section{Frequency occurring words}

A word (or word-form) may be quite frequent, but majority, or even all, of its occurrences might be in just one or two texts, in which case, although its frequency might look significant, its range might be quite small. The useful words for the learner are those words which are frequent and have a fairly wide rage that is those which occur across a wide variety of texts. Information about range can be presented in the form of statistical comparison between the occurrence of a word in one part of a corpus (e.g. just the scientific texts in the corpus) and its occurrence in the corpus as a whole. Any word that gets a differential of around 16 occurs with more or less the same frequency in the scientific texts as in the whole corpus. Any word with a lower differential is not very characteristic of scientific and learned English. Words with high differentials are characteristic of scientific and learned English (Michael McCarthy 40). We may see frequent occurring words in the contexts of one specialty; petroleum engineering ; natural gas, crude oil, kerogen, synthetic crude oil, pumping, well construction, fossil fuel, seismology, seismic waves, mineral deposits, sedimentary, igneous, metamorphic rocks. These technical words often occur in the context of petroleum engineering as well as mining engineering and they are considered as tokens and types.

\section{Tokens and types}

Lexical variation takes as its starting point the distinction between token and type. If a text is 100 words long, it is said to contain 100 tokens, but many of these tokens may be repeated within the text and this may give us a considerable lower total of types; she promised him she would write to him and write to him she did 'there are 14 tokens but some are repeated; there are only 8 types, (she', promised, him, would, write, to, and, did,). The ratio between tokens and types for this sentence is $14: 8$; the difference between the two numbers is great, indicating a fairly low load of differing items. In the sentence 'as the trees grow gold and brown, then autumn has come to replace summer', we have 14 tokens and 14 types, so the vocabulary load is quite high, with no repetition. Lexical variation counts do give us a rough measure of how many new items are introduced into a text as it unfolds; this may not be the same as new words for a language learner, but it can be a useful measure in predicting the likely degree of difficulty a text might present (Michael McCarthy.42). In the context of petroleum and mining engineering, tokens may occur more types;

1). Fossil fuels are fuels formed by natural processes such as anaerobic decomposition of buried dead organisms. The age of the organisms and their resulting fossil fuels is typically millions of years, and sometimes exceeds 650 million years. Fossil fuels contain high percentages of carbon and include coal, petroleum and natural gas.

2). Natural gas, once flared-off as an unneeded byproduct of petroleum production, is now considered a very valuable resource. Natural gas deposits are also the main source of the element helium.

According to the $1^{\text {st }}$ context, there are 51 tokens and 38 types in the petroleum engineering context, and we may see frequency words occurring in every sentence within the context, they are; Fossil fuels, fuels those occur also in other texts of this field.

According to the $2^{\text {nd }}$ context, there are 30 tokens and 26 types in the context of petroleum engineering, and we may see frequency words occurred in every sentence within the text, they are Natural gas.

\section{Conclusion}

In ESP classes, we focus on professionallyoriented context to teach and design the class, coloring it because there are some tokens and types which frequently occurs not only in one text but also does in other written contexts which tell us about the subject matter learners need to know. We study collocations which modify the word related to, and vocabulary words which are tokens and types. We analyzed technical text to find out whether how many times one word occur in other sentences within specialty, and how many tokens and types does it consist of. We addressed to the discussions of scholars on the issues of collocations, tokens and types, corpora. 


\begin{tabular}{|c|c|c|c|c|c|c|}
\hline \multirow{4}{*}{ Impact Factor: } & ISRA (India) & $=3.117$ & SIS (USA) & $=0.912$ & ICV (Poland) & $=6.630$ \\
\hline & ISI (Dubai, UAE & $=0.829$ & РИНЦ (Russia & $=0.156$ & PIF (India) & $=1.940$ \\
\hline & GIF (Australia) & $=0.564$ & ESJI (KZ) & $=8.716$ & IBI (India) & $=4.260$ \\
\hline & JIF & $=1.500$ & SJIF (Morocco & $=\mathbf{5 . 6 6 7}$ & OAJI (USA) & $=0.350$ \\
\hline
\end{tabular}

\section{References:}

1. Aisenstadt, E. (1981). Restricted collocations in English Lexicology and lexicography. ITL Review of Applied Linguistics 53: 53-61.

2. Bolinger, D. (1976). Meaning and memory. Forum Linguisticum, 1: 1-14.

3. Chomsky, N. (1965). Aspects of the Theory of Syntax. Cambridge Mass: MIT Press

4. Halliday, M. (1966). Lexis as a linguistic level. In Bazell, et al, 148-162.

5. McCarthy, M. (1998). Spoken Language and Applied Linguistics. Cambridge: Cambridge University Press.
6. McCarthy, M. (2006). Explorations in Corpus Linguistics. London: Cambridge University Press.

7. Mitchell, T. (1971). Linguistic 'goings-on': collocations and other lexical matters arising on the linguistic record. Archivum Linguisticum 2: 35-69.

8. Sinclair, J. (1987). Collocation: a progress report. In Steele and Threadgold, 319-331.

9. Sinclair, J. (1996). The search for the units of meaning. Textus IX: 75-106. 